\title{
Fruit quality of 'Eva' e 'Princesa' apples grown under nitrogen fertigation in semiarid climate
}

\author{
João M. de S. Miranda ${ }^{1}$, Ítalo H. L. Cavalcante ${ }^{2}$, Inez V. de M. Oliveira ${ }^{3}$, \\ Paulo R. C. Lopes ${ }^{4} \&$ Joston S. de Assis ${ }^{4}$ \\ ${ }^{1}$ Departamento de Agricultura/Universidade Federal de Lavras. Lavras, MG. E-mail: jmarcosmiranda@bol.com.br \\ ${ }^{2}$ Colegiado de Engenharia Agronômica/Universidade Federal do Vale do São Francisco. Petrolina, PE. E-mail: italo.cavalcante@univasf.edu.br (Autor \\ correspondente) \\ ${ }^{3}$ Companhia de Desenvolvimento dos Vales do São Francisco e do Parnaíba/PROJETEC. Petrolina, PE. E-mail: inezvilar@yahoo.com \\ ${ }^{4}$ Embrapa Semiárido. Petrolina, PE. E-mail: probertocl@hotmail.com; j-assis@uol.com.br
}

\section{Key words:}

Malus domestica

nitrogen

post-harvest

\begin{abstract}
A B S T R A C T
The production of high quality fruits is a necessary factor for the adaptation and production of plant species with economic viability. Thus, an experiment was conducted from July 2012 to January 2013 to evaluate the fruit quality of the 'Eva' and 'Princesa' apple cultivars as a function of nitrogen fertilization in Petrolina, PE, Brazil. The experimental design consisted of randomized blocks, with treatments distributed in a factorial arrangement $2 \times 4$, corresponding to apple cultivars (Eva and Princesa) and nitrogen doses (40; 80; 120 and $160 \mathrm{~kg}$ of $\mathrm{N} \mathrm{ha}^{-1}$ ), with four replications and three plants in each plot. The fruit characteristics, such as fruit mass, skin color (luminosity, chromaticity, and colour angle), size (width and length), pulp firmness, titratable acidity (TA), soluble solids (SS) and the SS/TA ratio, were recorded. Nitrogen doses do not affect fruit quality of studied apple cultivars. The fruit quality attributes are different between apple cultivars: fruit firmness, SS/TA ratio, fruit mass and fruit diameter are superior for Princesa cultivar, while the fruit length for Eva cultivar is superior.
\end{abstract}

\section{Palavras-chave:}

Malus domestica nitrogênio pós-colheita

\section{Qualidade de frutos de macieiras 'Eva' e 'Princesa' cultivadas sob fertirrigação nitrogenada em clima semiárido}

\footnotetext{
R E S U M O

A produção de frutos de qualidade constitui um fator necessário para a adaptação e produção de frutas com viabilidade econômica. Assim, o presente experimento foi conduzido de julho de 2012 a janeiro de 2013 com o objetivo de avaliar a qualidade física e química de frutos das macieiras 'Eva' e 'Princesa', em função da adubação nitrogenada em Petrolina-PE. Adotou-se delineamento em blocos casualizados em esquema fatorial $2 \times 4$, correspondentes a Cultivares de macieira (Eva e Princesa) e doses de nitrogênio em cobertura (40;80; 120 e $160 \mathrm{~kg} \mathrm{de} \mathrm{N} \mathrm{ha}^{-1}$ ) com quatro repetições e três plantas por parcela. As características dos frutos massa dos frutos, a coloração da casca (luminosidade, cromaticidade, e ângulo de cores), tamanho, firmeza da polpa, acidez titulável (AT), sólidos solúveis (SS) e a razão SS/ AT foram avaliadas. Não houve influência de doses de $\mathrm{N}$ nos atributos qualitativos de frutos da macieira, cultivares Eva e Princesa. A qualidade das maçãs difere entre as cultivares avaliadas: firmeza, razão SS/AT, massa do fruto e diâmetro dos frutos são superiores para a "Princesa", enquanto que o comprimento da "Eva" é superior.
} 


\section{INTRODUCTION}

Apple (Malus domestica Borkh.) is the main temperate fruit crop and its production in Brazil is concentrated in South region, especially Santa Catarina and Rio Grande do Sul states, where $94 \%$ of the Brazilian apples are cultivated (IBGE, 2014).

Due to the economic importance of apples, some studies have been conducted aiming to grow apples under different conditions from those required by this crop, detaching the researches under tropical climate in Ethopia (Ashebir et al., 2010) Kenia (Njuguna et al., 2004), China (Liu et al. 2010). In Brazil, apple cultivation has expanded for nontraditional regions of growing temperate fruit crops (Petri et al., 2011) detaching the research works performed successfully in semiarid climate of São Francisco Valley (Lopes et al., 2012, 2013; Santos, 2013; Oliveira et al., 2013) and west region of São Paulo State (Chagas et al., 2012) and Minas Gerais state (Oliveira et al., 2014). Additionally, 'Eva' and 'Princesa' are early season apple cultivars with low chilling exigency, adapted for regions with soft winter, which has made possible to grow apples in areas with different climates, such as Bahia and Pernambuco states (Lopes et al., 2012; 2013).

Due to apple has been cultivated out of its soil and climate comfort zone, for establishment of commercial orchards, some studies about agronomical management for pruning, pollination, pests and diseases control, beyond nitrogen fertilizing are necessary for both apple cultivars.

Nitrogen is very important for apple tree because its deficiency affects plant development, fruit yield and effective fruit set, beyond to favor early leaf drop and annual production alternation. The excess of $\mathrm{N}$, on the other side, also is harmful because it stimulates excessive plant development, with negative effects on bud and fruit quality, especially for color, conservation and incidence of physiological disorders (Ernani et al., 2008).

Despite the importance of nitrogen to the apple tree associated to its recent adaptation for different agroecological systems, nowadays the fertilizing recommendations for this crop are based on other states such as Santa Catarina, Rio Grande do Sul, Paraná, São Paulo and Minas Gerais. Thus for the effective supply of plant demand and an efficient $\mathrm{N}$ fertilizing it is necessary to consider the different climatic, soil and cultivar adaptation for Lower Basin of São Francisco Valley, a fact the highlights the importance of research works developed under field conditions.

The present work aimed at evaluating the physical and chemical quality of 'Eva' e 'Princesa' apple fruits as a function of nitrogen fertilizing in Petrolina, Pernambuco state, Brazil.

\section{Material AND Methods}

The experiment was conducted from July 2012 to January 2013 on an experimental orchard located in Campo Doro farm, in Petrolina $\left(09^{\circ} 21^{\prime} \mathrm{S}\right.$ and $40^{\circ} 34^{\prime} \mathrm{W}$; at an altitude of $375 \mathrm{~m}$ above sea level), Lower Basin of São Francisco Valley, Brazil.

The climate of this region is classified as Bswh (Köeppen), which corresponds to a semiarid region. During the execution of the experiment, the climatic data were collected by a meteorological station installed inside the experimental station
(Table 1), while physical and chemical characteristics of the soil (Quartzipsamments) before the experiment are in Table 2.

Before the execution of the experiment leaf samples were taken to access the plant nutritional status in marconutrients and micronutrients (Table 3). According to recommendations

Table 1. Mean air temperature, air humidity, rainfall, solar radiation and insolation during 2012

\begin{tabular}{|c|c|c|c|c|c|}
\hline Months & $\begin{array}{c}\mathrm{T} \\
\left({ }^{\circ} \mathrm{C}\right)\end{array}$ & $\begin{array}{l}\text { AH } \\
(\%)\end{array}$ & $\begin{array}{c}\text { Rainfall } \\
\text { (mm) }\end{array}$ & $\begin{array}{c}\text { SR } \\
\left(l y d^{-1}\right)\end{array}$ & $\begin{array}{l}\text { In } \\
\text { (h) }\end{array}$ \\
\hline January & 28.7 & 62.16 & 42 & 549 & 6.4 \\
\hline February & 29.4 & 48.82 & 16 & 510 & 6.0 \\
\hline March & 28.6 & 51.84 & 4 & 623 & 8.6 \\
\hline April & 28.3 & 52.01 & 2 & 556 & 9.3 \\
\hline May & 26.8 & 61.87 & 0 & 476 & 7.5 \\
\hline June & 25.9 & 62.03 & 4 & 443 & 7.8 \\
\hline July & 24.6 & 64.93 & 2 & 461 & 7.0 \\
\hline August & 24.3 & 63.98 & 2 & 501 & 8.1 \\
\hline September & 26.4 & 57.11 & 0 & 558 & 9.5 \\
\hline October & 27.7 & 56.36 & 0 & 623 & 9.7 \\
\hline November & 28.4 & 60.57 & 10 & 531 & 6.7 \\
\hline December & 28.3 & 54.59 & 12 & 594 & 7.6 \\
\hline Average & 27.3 & 58.0 & - & 535.4 & 7.9 \\
\hline
\end{tabular}

$\mathrm{T}$ - air temperature; AH - air humidity; SR - solar radiation; In - insolation

Table 2. Chemical and granulometric characteristics of the soil before the execution of the experiment at $0-20 \mathrm{~cm}$ and 20-40 cm soil depths

\begin{tabular}{|c|c|c|}
\hline \multirow{2}{*}{ Soil characteristic } & \multicolumn{2}{|c|}{ Soil depth (cm) } \\
\hline & $0-20$ & $20-40$ \\
\hline $\mathrm{pH}$ (in water) & 6.9 & 6.8 \\
\hline $\mathrm{Ca}^{2+} \mathrm{cmol}_{c} \mathrm{dm}^{-3}$ & 3.2 & 2.5 \\
\hline $\mathrm{Mg}^{2+} \mathrm{cmol}_{c} \mathrm{dm}^{-3}$ & 1.8 & 1.0 \\
\hline $\mathrm{Ca}+\mathrm{Mg} \mathrm{cmol}_{\mathrm{c}} \mathrm{dm}^{-3}$ & 5.0 & 3.50 \\
\hline $\mathrm{Al}^{3+} \mathrm{Cmol}_{\mathrm{c}} \mathrm{dm}^{-3}$ & 0.05 & 0.05 \\
\hline $\mathrm{H}+\mathrm{Al}^{3+} \mathrm{cmol}_{\mathrm{c}} \mathrm{dm}^{-3}$ & 2.8 & 2.47 \\
\hline $\mathrm{K}^{+} \mathrm{cmol}_{\mathrm{c}} \mathrm{dm}^{-3}$ & 0.20 & 0.16 \\
\hline $\mathrm{Na} \mathrm{cmol} \mathrm{Cm}^{-3}$ & 0.04 & 0.04 \\
\hline CEC $\mathrm{cmol}_{\mathrm{C}} \mathrm{dm}^{-3}$ & 8.04 & 6.17 \\
\hline$P-$ Melich $\mathrm{mg} \mathrm{dm}^{-3}$ & 29.77 & 25.66 \\
\hline \multirow[t]{2}{*}{ OM (\%) } & 0.6 & 0.44 \\
\hline & \multicolumn{2}{|c|}{$\mathrm{g} \mathrm{kg}^{-1}$} \\
\hline Clay & 7.8 & 47.4 \\
\hline Silt & 80.5 & 53.5 \\
\hline Sand & 911.7 & 925.0 \\
\hline
\end{tabular}

Table 3. Leaf nutrient concentrations of Eva and Princesa apple cultivars in May 2012 before the execution of the experiment.

\begin{tabular}{|c|c|c|}
\hline Nutrient ${ }^{(1)}$ & Eva & Princesa \\
\hline & \multicolumn{2}{|c|}{$\mathrm{g} \mathrm{kg}^{-1}$} \\
\hline $\mathrm{N}$ & 23.2 & 29.5 \\
\hline$P$ & 1.10 & 1.65 \\
\hline K & 14.94 & 18.01 \\
\hline $\mathrm{Ca}$ & 16.60 & 16.65 \\
\hline \multirow[t]{2}{*}{$\mathrm{Mg}$} & 4.20 & 4.85 \\
\hline & \multicolumn{2}{|c|}{$\mathrm{mg} \mathrm{kg}^{-1}$} \\
\hline B & 38.46 & 37.02 \\
\hline $\mathrm{Cu}$ & 90.00 & 73.00 \\
\hline $\mathrm{Fe}$ & 306.00 & 346.00 \\
\hline $\mathrm{Mn}$ & 123.00 & 187.00 \\
\hline $\mathrm{Zn}$ & 90.00 & 73.00 \\
\hline
\end{tabular}

(1) $\mathrm{N}$ was quantified using sulfur digestion by semi-micro-Kjeldahl method; $\mathrm{P}, \mathrm{K}, \mathrm{Ca}, \mathrm{Mg}$, $\mathrm{Cu}, \mathrm{Fe}, \mathrm{Mn}$ and $\mathrm{Zn}$ were determined through nitric-perchloric digestion; $\mathrm{B}$ was obtained by azomethine- $\mathrm{H}$ method, through dry solubilization 
of Nachtigall et al. (2004), four leaves per plant were taken from the middle part of the canopy at each cardinal point from 25 plants.

The experimental design was randomized blocks with treatments distributed in a factorial arrangement $(4 \times 2)$ referring to: i) apple cultivars (Eva and Princesa); and ii) nitrogen doses $\left(40,80,120\right.$ and $160 \mathrm{~kg}$ of $\left.\mathrm{N} \mathrm{ha}^{-1}\right)$ defined according to Ernani \& Dias (1999), with four replications and three plants in each parcel.

Apple cultivars studied in the experiment were 'Eva' and 'Princesa', grafted in 'Maruba' rootstock with 'M9' interstock. The orchard was planted in 2009 using a conduction system with a central leader. The spacing between the rows was $4.0 \mathrm{~m}$, and the spacing between the trees was $1.25 \mathrm{~m}$. The trees were drip-irrigated each day with ten self-regulated emitters per tree with a flow of $2 \mathrm{~L} \mathrm{~h}^{-1}$ based on daily evapotranspiration registers recorded by the Embrapa Meteorological Station and corrected according to the apple culture coefficient (Kc).

Hand defoliation and fruiting pruning were realized in July 2012, cutting weak and non-productive branches, beyond standardized all branched with $50 \mathrm{~cm}$ long. After hand defoliation (July 2012), the apple trees were pruned and treated with $0.8 \%$ hydrogen cyanamide and $3.0 \%$ mineral oil (Assist ${ }^{\circ}$ ), 3.0\% of color fix (Hi-Light ${ }^{\circ}$ ) and 2.0\% of adhesive (Iharaguen-S $S^{\circ}$ following the recommendation of Lopes et al. (2012).

Fruit thinning also was performed when fruit measured nearly $2.0 \mathrm{~cm}$ in diameter, keeping one or two fruits per floral bunch. The other cultural practices (pests and diseases management) were performed according to plant demands following the technical instructions of Nava et al. (2003).

The nitrogen source used was calcium nitrate $(15.5 \%$ of $\mathrm{N}$ ), applied twice a week, during 40 days, reaching 12 fertilizings through irrigation water. The first $\mathrm{N}$ fertilizing was performed at 40 days after breaking dormancy. All plants were also fertilized with potassium sulphate $\left(50 \%\right.$ of $\left.\mathrm{K}_{2} \mathrm{O}\right)$, triple superphosphate $\left(45 \%\right.$ of $\mathrm{P}_{2} \mathrm{O}_{5}$ ), magnesium sulphate ( $15 \%$ of $\mathrm{Mg}$ ), boric acid (17\% of B) through irrigation water, according to instructions of Nava et al. (2003). Zinc (Coda Zinc, $10.4 \%$ of $\mathrm{Zn}$ ), magnesium (Coda $\mathrm{Mg}^{\circ}, 6.6 \% \mathrm{de} \mathrm{Mg}$ ) and iron (Codamin $\mathrm{Br}^{\circ}, 2.0 \%$ of $\mathrm{Fe} ; 1.0 \%$ of $\mathrm{Zn}$; and $10 \%$ of amino acid) were leaf applied in 09/17/2012.

Apples of 'Eva' and 'Princesa' cultivars were manually harvested once a week from December 2012 to January 2013, during the first hours of the day, under commercial maturation that is characterized by yellow background skin color and red superficial skin color (Santos, 2013). The fruits were placed in plastic bags and taken to the Post Harvest Physiology Laboratory of the Brazilian Agricultural Research Corporation (Embrapa Semiarido), Petrolina, Brazil.

For fruit analysis six fruits were used in each parcel, reaching 24 fruits per treatment, which were physically analyzed for fruit mass, skin color [luminosity parameters (darkness, varying from $0=$ dark to $100=$ white), Chroma (light saturation or light intensity, varying from $0=$ impure color to $60=$ pure color) and color angle or Hue angle (real color, $0^{\circ}=$ red, $90^{\circ}=$ yellow, $180^{\circ}=$ green, $270^{\circ}=$ blue and $360^{\circ}$ = black)], fruit size (diameter and width) and pulp firmness. After these analyses, all fruits were processed using a fruit centrifuge and the pulps were used for analyses of titratable acidity (TA), soluble solids (SS) and ratio SS/TA, following the methods described by IAL (1985).

Statistical analyses included analysis of variance for diagnostic of significant effect between apple cultivars on each nitrogen dose using ' $F$ ' test, mean separation of apple cultivars using Tukey test and regression analysis of nitrogen doses. All calculations were performed using the Assistat and Sigmaplot softwares.

\section{Results AND Dicussion}

As can be seen in Table 4 all variables studied affected apple cultivar $(\mathrm{P}<0.01)$, while the significant interaction between $\mathrm{N}$ doses and apple cultivar was recorded for fruit width $(\mathrm{P}<0.01)$, and there was no effect of $\mathrm{N}$ doses for any variable recorded.

Titratable acidity (TA) and soluble solids (SS) were significantly higher for 'Eva' in comparison to 'Princesa' apple cultivar (Table 4), which could be caused by endogenous factors of genetics of both cultivars since 'Eva' is grown for fruit yield while 'Princesa' is used as a pollinator cultivar (Nachtigall, 2004). This result is in agreement with Santos (2013) and Chagas et al. (2012) also in study about Eva and Princesa apple cultivars. Despite the 'Eva' have presented significantly superiority for SS, the SS/TA ratio was higher in fruits of 'Princesa' (Table 4) that occurred due to the strongly lower TA of 'Princesa' fruits. This way, Cavalcante et al. (2012) argued that higher TA and SS individually present a false parameter for fruit quality, while the SS/TA ratio has been considered a practical and reliable variable, especially for fruits consumed as fresh fruit. When compared to the data quoted in the scientific literature the average SS/TA ratio values of the present study are higher than those recorded by Chagas et

Table 4. Fruit characteristics [titratable acidity (TA), soluble solids (SS), SS/TA ratio, pulp firmness, mass, width and length] of apples 'Eva' and 'Princesa' as a function of nitrogen fertilizing

\begin{tabular}{|c|c|c|c|c|c|c|c|}
\hline \multirow{2}{*}{ Variation source } & \multirow{2}{*}{$\begin{array}{c}\text { TA } \\
\text { g malic acid } 100 \mathrm{~g}^{-1}\end{array}$} & \multirow{2}{*}{$\begin{array}{l}\text { SS } \\
(\%)\end{array}$} & \multirow{2}{*}{ SS/TA } & \multirow{2}{*}{$\begin{array}{l}\text { Firmness } \\
\text { (N) }\end{array}$} & \multirow{2}{*}{$\begin{array}{l}\text { Mass } \\
(\mathrm{g})\end{array}$} & Width & Length \\
\hline & & & & & & \multicolumn{2}{|c|}{$(\mathrm{mm})$} \\
\hline Doses of $\mathrm{N}$ & $1.82^{\mathrm{ns}}$ & $0.34^{\mathrm{ns}}$ & $0.35^{\mathrm{ns}}$ & 0.64 ns & $2.37^{\text {ns }}$ & $2.30^{\mathrm{ns}}$ & $1.24^{\mathrm{ns}}$ \\
\hline Apple cultivar (cv.) & $424.89^{* *}$ & $16.7^{* *}$ & $247.5^{* *}$ & $45.77^{* *}$ & $46.95^{* *}$ & $82.09^{* *}$ & $21.0^{*}$ \\
\hline Eva & $0.57 \mathrm{a}$ & $16.0 \mathrm{a}$ & $28.48 \mathrm{~b}$ & $51.86 \mathrm{~b}$ & $116.8 \mathrm{~b}$ & $60.88 \mathrm{~b}$ & $64.3 \mathrm{a}$ \\
\hline Princesa & $0.38 \mathrm{~b}$ & $15.3 \mathrm{~b}$ & $41.01 \mathrm{a}$ & $58.60 \mathrm{a}$ & $148.3 \mathrm{a}$ & $68.09 \mathrm{a}$ & 60. b \\
\hline SMD & 0.02 & 0.34 & 1.65 & 2.07 & 9.58 & 1.65 & 1.84 \\
\hline Interaction N x cv. & $2.95^{\mathrm{ns}}$ & $0.34^{\mathrm{ns}}$ & $0.78^{\mathrm{ns}}$ & $1.27^{\mathrm{ns}}$ & $0.35^{\mathrm{ns}}$ & $0.05^{*}$ & $0.46^{\text {ns }}$ \\
\hline C.V. & 5.49 & 2.98 & 6.48 & 5.10 & 9.83 & 3.49 & 4.03 \\
\hline
\end{tabular}

cV. - cultivar; V. C. - variation coefficient; SMD - significant minimum difference; ${ }^{* \star}$ - significant at $\mathrm{P}<0.01 ;{ }^{*}-$ Significant at $\mathrm{P}<0.05$; Data followed by different letters in columns are significantly different according to Tukey test 
al. ( 2012) for Eva and Princesa apple cultivars (24.2 and 23.8, respectively). According to Wu et al. (2007) apples with higher soluble solids and organic acids are more recommended for concentrated juice production, while fruits with higher SS/TA ration are sweet and able to consumption as fresh fruit. Indeed, whether considered this parameter, both apple cultivars studied presented averages higher than 20, thus they are considered sweet cultivars and able for consumption as fresh fruit, according to recommendations of Chagas et al. (2012).

The average pulp firmness for cv. 'Princesa' was higher than that recorded for cv. 'Eva', although for both cultivars the values are much lower than those registered by Santos (2013) for apples grown in Petrolina, Brazil. On the other hand, Chagas et al. (2012) evaluated 'Eva' and 'Princesa' in west region of São Paulo State and recorded the average values of 51.7 and 53.9 $\mathrm{N}$, respectively, thus lower than those reported in the present study. For fruit firmness comparison between cultivars is relevant to detach that the high fruit firmness is a remarkable characteristic of cv. 'Princesa' (Oliveira et al., 2014), with firm and crisp fresh pulp that is very important both for post-harvest storage and taste of most consumers, although in southern Brazil (Oliveira et al., 2014) this cultivar be considered more appropriate for industrial processing.

According to Domínguez (2008), the UPOV (International Union for the Protection of New Varieties of Plants) classifies as 'very soft' the fruits with pulp firmness lower than $55.9 \mathrm{~N}$, 'soft' the pulp firmness between $55.9 \mathrm{~N}$ and $68.3 \mathrm{~N}$, 'average' the pulp firmness between $68.3 \mathrm{~N}$ and $80.8 \mathrm{~N}$ and 'hard' the pulp firmness between $80.8 \mathrm{~N}$ and $93.5 \mathrm{~N}$. Therefore, considering this parameter, cv. 'Eva' is 'very soft' and cv. 'Princesa' 'soft.' Pulp firmness is very important for apple cultivation, as it is used to standardize the harvest time (Nachtigall, 2004), because it determines the penetration resistance break, thus an indicative of fruit consistence.

In relation to fruit mass, cv. 'Princesa' fruits were 22\% higher than cv. 'Eva' fruits (Table 4), surpassing even results recorded for 'Gala' and 'Fuji' that presented average mass of 137.7 and $135.9 \mathrm{~g}$, respectively, when grown under temperate climate (Dabul \& Ayub, 2006; Fioravanço et al., 2010). Chagas et al. (2012) in a study realized in west region of São Paulo State also registered superiority of 'Princesa' in relation to 'Eva' with average mass of 145 and $141 \mathrm{~g}$, respectively. The other side, independently of apple cultivar, the average values of Table 4 are lower than 225.1-275.1 g range reported by Iglesias et al. (2008) for cv. 'Fuji' in Spain.

The differences between cultivars for fruit mass were enough to cause a different fruit classification, because when comparing fruit mass according to the criterion defined by the Brazilian Association of Apple Growers (ABPM, 2015) the cv. 'Eva' fruits are classified in class caliber 150, while cv. 'Princesa' fruits in class 120. It detaches that in each region the plants are subjected to oscillations on air temperature, rainfall and soil that can stimulate or suppress genetic composition aspects, affecting phenotypical expression, including fruits (Oliveira et al., 2014).

'Eva' fruits presented elongated shape, with length invariably higher than width, while cv. 'Princesa' produced fruits flattened shape, i.e., fruit width greater than length
(Table 4). The width average values recorded in the present study (Table 4) are compatible to those averages reported by Chagas et al. (2012) for 'Eva' (63.7 mm) and 'Princesa' (67.9 $\mathrm{mm}$ ) in west region of São Paulo State, and higher than those registered by Santos (2013) for the same apple cultivars grown in Lower Basin of São Francisco Valley.

Several factors affect apple fruit size and shape, such as genetics, climate conditions during flowering, cell division and expansion, number of fruits per leaf area unit, number of seeds per fruit, fruit distribution and position on plant, water and nutrient supply and plant age (Nava et al., 2003).

Fruit width, independently of apple cultivar, increased with nitrogen fertilizing enhancement until $169 \mathrm{~kg} \mathrm{ha}^{-1}$ for $\mathrm{cv}$. 'Eva' and $176 \mathrm{~kg} \mathrm{ha}^{-1}$ for $\mathrm{cv}$. 'Princesa, and this increase was immediately followed by decay (Figure 1). This result disagrees of those quoted by Nava et al. (2007) who verified that apple size is more affected by the number of fruits per plant in relation to the nitrogen fertilizing provided. However, according to Ernani et al. (2008), the nitrogen fertilizing in the first forty-five days after flowering, during cell division phase favors fruit growth and, consequently, fruit width, which probably occurred in this study, since at this time all plants had already received two nitrogen fertigations in their respective doses.

A.

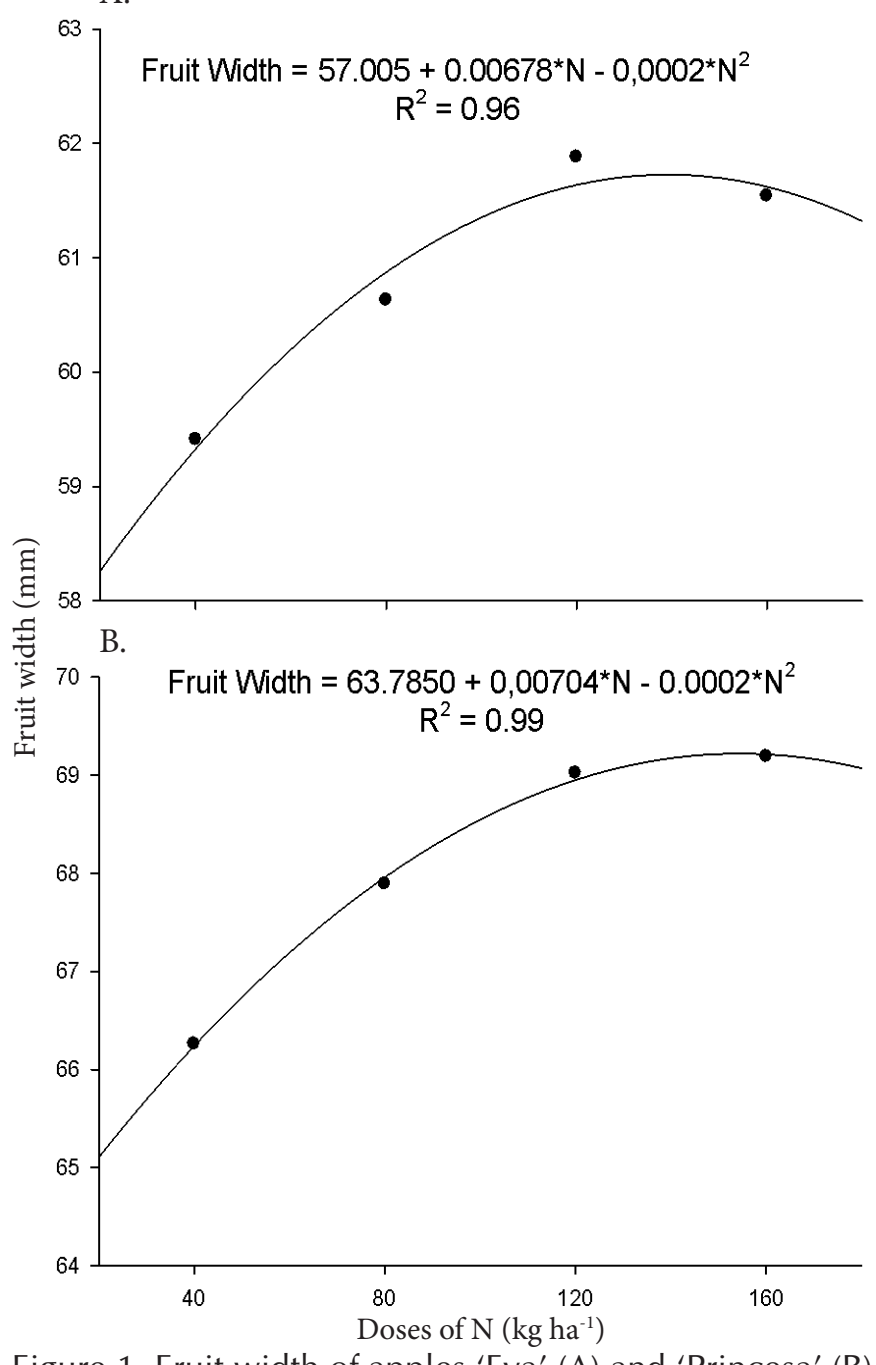

Figure 1. Fruit width of apples 'Eva' (A) and 'Princesa' (B) as a function of nitrogen fertilizing 
Table 5. Resume of variance analyses for superficial skin color and background skin color for 'Eva' and 'Princesa' apples as a function of nitrogen fertilizing

\begin{tabular}{|c|c|c|c|c|c|c|}
\hline \multirow{2}{*}{ Variation source } & \multicolumn{3}{|c|}{ Superficial skin color } & \multicolumn{3}{|c|}{ Background skin color } \\
\hline & ${ }^{1} \mathrm{~L}$ & C & $\mathrm{H}$ & $L$ & C & $\mathrm{H}$ \\
\hline Doses of $\mathrm{N}$ & $0.82^{\mathrm{ns}}$ & $1.23^{\mathrm{ns}}$ & $0.96^{\mathrm{ns}}$ & $1.04^{\mathrm{ns}}$ & $1.47^{\mathrm{ns}}$ & $0.58^{\mathrm{ns}}$ \\
\hline Apple cultivar (cv.) & $34.74^{* *}$ & $26.8^{* *}$ & $2.95^{\mathrm{ns}}$ & $8.26^{* *}$ & $17.23^{\star \star}$ & $6.75^{*}$ \\
\hline Eva & $36.77 \mathrm{a}$ & $24.37 \mathrm{a}$ & $35.41 \mathrm{a}$ & $50.84 \mathrm{a}$ & $22.22 \mathrm{a}$ & $89.96 \mathrm{a}$ \\
\hline Princesa & $32.55 \mathrm{~b}$ & $19.65 b$ & $31.68 \mathrm{a}$ & $49.68 \mathrm{~b}$ & $20.24 b$ & $82.38 b$ \\
\hline LSD & 1.49 & 1.89 & 4.52 & 0.85 & 0.99 & 6.07 \\
\hline Interaction N x cv. & $1.51^{\mathrm{ns}}$ & $0.97^{\mathrm{ns}}$ & $1.63^{\text {ns }}$ & $0.18^{\mathrm{ns}}$ & $0.35^{\mathrm{ns}}$ & $1.17^{\mathrm{ns}}$ \\
\hline V.C. & 5.84 & 11.72 & 18.33 & 2.32 & 6.35 & 9.58 \\
\hline
\end{tabular}

cv. - cultivar; V. C. - variation coefficient; LSD - Least significant difference; ${ }^{* *}$ - significant at $\mathrm{P}<0.01$; ${ }^{*}$ - Significant at $\mathrm{P}<0.05$; Data followed by different letters in columns are significantly different according to Tukey test. ${ }^{1} \mathrm{~L}$ - luminosity; $\mathrm{C}$ - chroma; $\mathrm{H}$ - Hue angle

In general, apple fruit format is characterized by cultivar and it is important for marketing, although its real importance is for phytopathology, since changes in fruit shape may predispose to a higher incidence of moldy core, one of the main apple diseases (Nachtigall, 2004).

Apple cultivar significantly affected the superficial skin color and background skin color, except for $\mathrm{H}$ (Hue) of superficial skin that not varied between apple cultivars (Table 5). There was no significant effect of nitrogen doses neither nitrogen dose $\mathrm{x}$ apple cultivar interaction.

'Princesa' cultivar presented lower luminosity (L) of superficial skin color, indicating a darker red skin (Table 5). Santos (2013) in study about 'Eva' and 'Princesa' apple cultivars in Petrolina, Brazil reported $\mathrm{L}$ average values of 35 , thus compatible to those quoted in the present study. On the other hand, the averages included in Table 5 are lower than those recorded by Chagas et al. (2012) which ranged from 45.2 ('Eva') to 46.4 ('Princesa'). It detaches that skin luminosity represent surface brightness and follows a scale from 0 (dark) to 100 (white color).

'Princesa' apple cultivar presented less intense superficial skin color [Chroma (C)] in relation to 'Eva' (Table 5), values which are compatible to those found by Santos (2013) who registered 24. The Chroma variable defines the color intensity, assuming values near zero for neutral colors (grays) and nearly 60 to vivid colors that, for apples develops early and varies greatly as a function of environmental factors and cultivars reason whereby the apple skin color is not considered a maturation index (Iglesias et al., 2008).

Pell angle or Hue values were not affected by apple cultivar (Table 5), but, independently of cultivar, fruits were more red (lower Hue angle) than those produced by Santos (2013), who registered $60^{\circ}$ and $41^{\circ}$ for 'Eva' and 'Princesa', respectively. In addition, Chagas et al. (2012) observed $37.7^{\circ}$ ('Eva') and $42.7^{\circ}$ ('Princesa') and Angelis et al. (2011) reported 39.5 for cv. Gala.

In relation to Hue angle Iglesias et al. (2008) argue that the lower color angle (Hue), the better the skin red color, revealing the visual quality of both apple cultivars produced under semi-arid climate.

In a general form it is important to detach the nonsignificant effect of nitrogen doses applied through fertigation on all variables studied (Tables 4 and 5). This result was also identified in the scientific literature about different apple cultivars (Ernani et al., 2008; Roussos \& Gasparatos, 2009; Han et al., 2011; Li-Zhi et al., 2012) and it could be explained by the low nitrogen demand of apple tree whether compared to other fruit species, as Ernani et al. (2008) detach.
In the present work, despite the low soil organic matter where the experiment was performed [ $(0.6 \%)$ Table 2], plants of both apple cultivars were adequately supplied in nitrogen (23.2 and $29.5 \mathrm{~g} \mathrm{~kg}^{-1}$, respectively for 'Eva' and 'Princesa') according to the stated adequate range of supply defined by Malavolta et al. (1997) (23 to $25 \mathrm{~g} \mathrm{~kg}^{-1}$ ) and, indeed, it should be enough to fruit production with quality of both cultivars.

\section{Conclusions}

1. Nitrogen fertilizing is not necessary for fruit production of apples 'Eva' and 'Princesa', during one cycle in Petrolina, when the plants are $\mathrm{N}$ supplied at the beginning of the cycle.

2. The fruit quality attributes for apple depends on cultivar: fruit firmness, SS/TA ratio, fruit mass and fruit width are higher on cv. 'Princesa', while fruit length is higher on cv. 'Eva' and, both of them produce fruits compatible to market exigencies when grown under semi-arid conditions.

\section{Literature Cited}

ABPM - Brazilian Association of Apple Growers (ABPM). 2015. Proposta para normas de classificação para maçã. <http:// www. abpm.org.br>. 21 Jan. 2015

Angelis, V.; Sánchez, E.; Tognetti, J. Timing of nitrogen fertilizantion influences color and anthocyanin content of apple (Malus domestica Borkh. cv 'Royal Gala') fruits. International Journal of Fruit Science, v.11, p.364-375, 2011. http://dx.doi.org/10.1080/1 5538362.2011 .630298

Ashebir, D. Deckers, T.; Nyssen, J.; Bihon, W.; Tsegay, A.; Tekie, H.; Poesen, J.; Haile, M.; Wondumagegneheu, F.; Raes, D.; Behailu, M.; Decker, J. Growing apple (Malus domestica) under tropical mountain climate conditions in Northern Ethiopia. Experimental Agriculture, v.46, p.53-65, 2010. http://dx.doi.org/10.1017/ S0014479709990470

Cavalcante, Í. H. L.; Cavalcante, L. F.; Miranda, J. M. S. Martins, A. B. G. Physical and chemical characteristics of tropical and nonconventional fruits. In: Valdez, B. Food Industrial Processes - Methods and Equipment. Rijeka: InTech, 2012. cap.1, p.1-16.

Chagas, E. A.; Chagas, P. C.; Pio, R.; Bettiol Neto, J. E.; Sanches, J.; Carmo, S. A.; Cia, P.; Pasqual, M.; Carvalho, A. dos S. Produção e atributos de qualidade de cultivares de macieira nas condições subtropicais da região Leste Paulista. Ciência Rural, v.42, p.17641769, 2012. http://dx.doi.org/10.1590/S0103-84782012001000008 
Dabul, A. N. G.; Ayub, R. A. Effects of promalin $(6 \mathrm{BA}+\mathrm{GA} 4+7)$ on growth and development of apple fruits (Malus domestica, Borkh.) cv. Gala. Semina: Ciências Agrárias, v.27, p.199-204, 2006. http://dx.doi.org/10.5433/1679-0359.2006v27n2p199

Domínguez, M. M. Estudio de la variabilidad morfológica en el Banco Nacional de Germoplasma de Manzano, Zaragoza. Zaragoza: Escuela Universitaria Politécnica La Almunia de Doña Godina, 2008. 99 p. Trabalho de conclusão de curso

Ernani, P. R.; Dias, J. Soil nitrogen application in the spring did not increase apple yield. Ciência Rural, v. 29, p.645-649, 1999. http:// dx.doi.org/10.1590/S0103-84781999000400013

Ernani, P. R.; Rogeri, D. A.; Proença, M. M.; Dias, J. Addition of nitrogen had no effect on yield an quality of apples in an high density orchard carrying a dwarf rootstock. Revista Brasileira de Fruticultura, v.30, p.1113-1118, 2008. http://dx.doi.org/10.1590/ S0100-29452008000400044

Fioravanço, J. C.; Almeida, G. K.; Silva, V. C. Efeito da Promalina $(\mathrm{GA} 4+7+6 \mathrm{BA})$ na produção e desenvolvimento dos frutos da macieira cv. Royal Gala. Revista de Ciências Agroveterinárias, v.9, p.143-149, 2010.

Han, Y.; Zheng, D.; Vimolmangkang, S.; Khan, M. A.; Beever, J. E.; Korban, S. S. Integration of physical and genetic maps in apple confirms whole-genome and segmental duplications in the apple genome. Journal of Experimental Botany, v.62, p.51175130, 2011. http://dx.doi.org/10.1093/jxb/err215

IAL - Instituto Adolfo Lutz. Normas analíticas, métodos químicos e físicos para análise de alimentos. 1 ed. São Paulo: IAL, 1985. 371p.

IBGE - Instituto Brasileiro de Geografia estático. 2014. Censo agropecuário 2014:lavoura permanente e temporária. <http:// www.ibge.gov.br/estadosat/perfil.php?sigla=rs>. 22 Dez. 2014.

Iglesias, I.; Echeverría, G.; Soria, Y. Differences in fruit colour development, anthocyanin content, fruit quality and consumer acceptability of eight 'Gala' apple strains. Scientia Horticulturae, v. 119, p.32-40, 2008. http://dx.doi.org/10.1016/j.scienta.2008.07.004

Liu, C.; Han, M.; Zhang, L. The effects of fertilizer application at early summer on growth, yield and quality of Fuji apple in Weibei Highland. Agricultural Research, v.26, p.124-137, 2008.

Li-Zhi, Y. Hai-xia, V.; Gan, W.; Xue-yan, S. The input of chemical fertilizer and soil nutrient in apple orchard. Asian Agricultural Research, v.4, p.63-65, 2012.

Lopes, P. R. C.; Oliveira, I. V. M.; Silva, R. R. S.; Cavalcante, İ. H. L. Caracterização fenológica, frutificação efetiva e produção de maçãs 'Eva' em clima semiárido no Nordeste Brasileiro. Revista Brasileira de Fruticultura, v.34, p.1277-1283, 2012. http://dx.doi. org/10.1590/S0100-29452012000400038
Lopes, P. R. C.; Oliveira, I. V. M.; Silva, R. R. da S.; Cavalcante, Í. H. L. Growing Princesa apples under semiarid conditions in northeastern Brazil. Acta Scientiarum. Agronomy, v.35, p.93-99, 2013. http://dx.doi.org/10.4025/actasciagron.v35i1.15066

Malavolta, E.; Vitti, G. C.; Oliveira, S. A. Avaliação do estado nutricional das plantas: princípios e aplicações. 2.ed. Piracicaba: Potafos, 1997. 281p.

Nachtigall, G. R. Maçã: produção. Bento Gonçalves: Embrapa Uva e Vinho, 2004. 171p.

Nava, G.; Basso, C.; Nuernberg, N. J.; Melo, G. W.; Nachtigall, G. R.; Suzuki, A. Solos e nutrição. In: Sanhueza, R. M. V. Produção integrada de maçãs no Brasil. Bento Gonçalves: Embrapa Uva e Vinho, 2003. Sistema de Produção, 1)<http://sistemasdeproducao. cnptia.embrapa.br/FontesHTML/Maca/ProducaoIntegradaMaca/ solos.htm> 20 Jun. 2012.

Nava, G.; Nuenrberg, N. J.; Pereira, A.; Dechen, A. R. Adubação de crescimento de macieira cv. Catarina sobre porta-enxerto marubakaido em São Joaquim-SC. Revista Brasileira de Fruticultura, v.29, p.359-363, 2007. http://dx.doi.org/10.1590/ S0100-29452007000200033

Njuguna, J. K.; Leonard, S. W.; Teddy, E. M. Temperate fruits production in the tropics: a review on apples in Kenya. HortScience, v.39, p.841-841, 2004.

Oliveira, D. L.; Alvarenga, A. A.; Gonçalves, E. D.; Malta, M. R. Qualidade de maçã cv. Eva produzida em duas regiões de Minas Gerais. Brazilian Journal of Food Technology, v.17, p.269-272, 2014. http://dx.doi.org/10.1590/1981-6723.4912

Oliveira, I. V. M.; Lopes, P. R. C.; Silva-Matos, R. R. S.; Cavalcante, Í. H. L. Fenologia da macieira, cv. Condessa no vale de São Francisco. Revista de Ciências Agrárias, v.36, p.23-30, 2013.

Petri, I. L.; Leite, G. B.; Couto, M.; Francescatto, P. Avanços na cultura da macieira no Brasil. Revista Brasileira de Fruticultura, volume especial, p.48-56, 2011. http://dx.doi.org/10.1590/S010029452011000500007

Roussos, P. A.; Gasparatos, D. Apple tree growth and overall fruit quality under organic and conventional orchard management. Scientia Horticulturae, v.123, p.247-252, 2009. http://dx.doi. org/10.1016/j.scienta.2009.09.011

Santos, A. C. B. Crescimento, maturação e conservação pós-colheita de maçãs cultivares "Eva" e "Princesa" na região do Submédio do São Francisco. Juazeiro: UNEB, 2013. 95p. Dissertação Mestrado Wu, J. ; Gao, H.; Zhao, L.; Liao, X.; Chen, F.; Wang, Z.; Hu, X. Chemical compositional characterization of some apple cultivars. Food Chemistry, v.103, p.88-93, 2007. http://dx.doi. org/10.1016/j.foodchem.2006.07.030 